\title{
FOREWORD
}

\section{LINDA WINER}

If this book were a movie, it should begin with an image from the epilogue. There, in a '6os café called Riker's on Sheridan Square, all the dashing young men (yes, exclusively men) who created what we now package into a romantic blur called off-off-Broadway would be hanging out and drinking, smoking whatever, and talking nonstop about the theater.

Or so Lanford Wilson suggested in 2008 in a dialogue with Jeffrey Sweet printed in the last chapter of this invaluable book. By then, Riker's was long gone, and we lost Wilson, too soon, in 2011. But his words, remembering all the night owls - he and Sam Shepard were "worse than anyone" - conjure a creative community that I imagine most theater lovers want to believe exists in New York, in London, and everywhere theater is made.

For the most part, however, playwriting begins as a solo impulse and, despite all the rich collaborations described in the following chapters, remains a solitary obsession. A plumed muse of inspiration, seldom documented, will not likely be perched on any shoulder. Perhaps more typically, Lynn Nottage had the words "Sustain the com- 
plexity" taped over her computer while writing her 2009 Pulitzer Prize-winning drama, Ruined.

And when the lonely work is finished for the day, all the different playwrights (finally, not just men) do not head to their special gathering place to crow and complain about this art, this business, and this drive that form the basis for what we see on the stage.

Instead, Sweet, himself a playwright, has come up with the next best thing, a theoretical clubhouse where the rest of us can listen in on thoughts that, except perhaps in classrooms, only lurk and roil as internal monologues in the private worlds of people who write for the theater. Though the playwrights can't physically cross paths in these pages, obviously, they respond here to Sweet's questions, encyclopedic prods, and gentle challenges in ways that feel more like conversations - arguments, even - that lower the drawbridge over the moat that separates a playwright's intentions from the public result. What a pleasure it is to follow threads and dividing lines on many subjects through these chapters.

The collection here concentrates on what Sweet convincingly divides into the post-Edward Albee playwrights, most of them Americans who have managed to make careers away from commercial Broadway, and the post-John Osborne writers, all British here, beginning with David Hare. As Hare, author of such deliciously rigorous plays as Plenty and Via Dolorosa, puts it, Osborne's Look Back in Anger, that legendarily explosive 1956 blue-collar drama, did "so much for all the rest of us" by not being "in hock to literature" or "in hock to show business."

In many ways, including the source of ideas and the mission of theater, it feels alarmingly easy to separate playwrights by nationality. Despite the dangers of glib generalizations, however, American theater is most often seen through what Kwame Kwei-Armah, the British playwright and artistic director of Baltimore's Center 
Stage, describes as the "lens of the family." The English are bred on what's commonly known as state-of-the-nation plays. In other words, much American theater involves dysfunctional families and relationships unraveling at or near home. English plays - most recently, King Charles III and The Audience-go for the big political picture, some even presuming to imagine conversations between living politicians. This distinction is neither good nor bad. For the most part, as these interviews show and tell, it simply is.

So yes, ideas must come from somewhere-but from where? And, while we're asking impertinent questions, for what purpose?

For those who like their cultural sensibilities as smackdowns, consider two very different plays: Marsha Norman's 1983 Pulitzer Prizewinning 'night, Mother, which is set in the final hours before a daughter's suicide, and Hare's Stuff Happens, a state-of-two-nations drama that uses transcripts from England and this country about the start of the first Iraq War. Norman firmly believes that playwrights should "write out of their stuff." By this, she means that which has been "assigned to you by the universe and your upbringing and your presence on the planet and your accident of birth." She defines her own stuff, evocatively, as "the trapped girl." To Norman, what the theater can do best is "make people feel not so alone." Well, across the ocean and around the philosophical universe, there is Hare, daring playwrights to tackle political "taboos": "Even if you can't change the world, nevertheless you at least can air the opportunity to change the world." Hare takes pride in that state-of-the-nation play. Norman interrupts-if you can imagine them in the same room - to explain that Americans don't do state-of-the-nation plays because "we're not one people here."

And what about scale? Is it national personality or money that decides the size of the cast and the canvas on which the playwright works? Donald Margulies, winner of the 2000 Pulitzer Prize for Dinner with Friends, has roamed impressively around big subjects but 
with chamber-sized casts and an emphasis on relationships. He is practical: "I don't permit myself to think on a larger canvas." If he wants his work to be produced by American nonprofit theaters, he avoids what he calls the "fiscally unwieldy play." Hare, as you might guess, has no patience for Americans who color within the limitations of our theater. He mentions the monumental experiments of Eugene O’Neill, then Tony Kushner's epic Angels in America. As Hare sees it, Kushner wrote "for a theater that did not exist" - and such theater came into being "because he wrote this great play."

Lest we glorify the English theater's receptiveness to large work, Sweet helpfully enlightens us about the playfully named but clearly serious Monsterists, cofounded ten years ago by Moira Buffini and nine other young English writers assigned to work in the small studio at the National Theatre. They couldn't help but notice that the big stages were used for dead or long-established playwrights, what she calls the "silverback writers." The group even had a manifesto - when was the last time anyone in American theater said that word without snickering? - and a symposium to ask how the next generation, marginalized in black-box theaters with chamber-sized casts, could learn to write to scale. Opportunities actually followed.

And shattering all conventional wisdom is Robert Schenkkanself-taught and a former actor-who breaks expectations on his own time. In 1992, he came from what some New Yorkers considered nowhere to win the Pulitzer Prize for The Kentucky Cycle, a two-night epic that traced two hundred years in the lives of more than seventy characters. Twenty-two years later, there he was again, winning the 2014 Tony Award for All the Way, a fact-based drama about Lyndon Baines Johnson and the passage of civil rights legislation. Perhaps not incidentally, the Broadway production starred Bryan Cranston in his first sighting since Breaking Bad. Still, the success was not merely star-driven. As Schenkkan says, with disarming simplicity, "I write what interests me in the moment. It's not like I think, 'Wow, what

\section{Foreword}


the market really needs is a three-hour, seventeen-actor epic about LBJ. That'll be hot.'” Even more unlikely, HBO had him write the screenplay for a movie adaptation - and this was just the first evening in a two-night LBJ saga. The Great Society, about the president and Vietnam, had its premiere at the Oregon Shakespeare Festival, where both were commissioned as part of its unusually ambitious American Revolutions Project. At this writing, the final half has not been seen on Broadway. Concerning theatrical missions, Schenkkan again breaks with molds and trends. "There is a strong argument to be made that theater should be doing what it originally did," he says, blithely swimming against the mainstream with "big, epic communal story events out of our shared history."

On collaboration, there are surprisingly few differences. Schenkkan insists on being involved in everything, including the design process and rehearsals - which, significantly in his unusual case, involve the same community of actors. He appreciates all suggestions, but "ultimately it's my decision as to which is the best idea in the room."

A formidable exception is Albee, whose death in 2016 at eightyeight has made the theater a starkly smaller place. As Sweet points out during his lively conversation with British playwright Bryony Lavery, author of the haunting drama Frozen, Albee never was good about sharing. As Sweet describes the Albee process, the boundarybreaking master with three Pulitzer Prizes "walks around for a year, thinks and thinks and thinks, and then writes it all down in two or three days. And he changes barely a word after that." When I interviewed Albee in 2007 for a cover story in Newsday on his eightieth birthday, he elaborated a bit further on his process. "I know something is happening but I wait a long time until I can't do anything else and then I write it down. I see the play and I hear it as a play being performed on stage... I see it as a play that I'm watching." Arthur Kopit's dark farce Oh Dad, Poor Dad, Mamma's Hung You in the Closet and I'm Feelin' So Sad and Albee's Who's Afraid of Virginia 
Woolf? shocked Broadway around the same time in the early 1960 s. Kopit remembers that neither playwright wanted to be called absurdist. He speaks instead of the "dark humor and the danger" being similar to what Lenny Bruce was doing, how "something could be funny that you would have thought appalling a short while ago."

Christopher Durang, the irreverent satirist who identifies Albee's The American Dream as an inspiration and doesn't mind the absurdist label, will surprise no one by his admission, "I'm definitely not the kind who can outline." Nottage, who says she writes "around my stuff," in contrast to Norman's theory of writing one's own "stuff," is the rare playwright who makes outlines. But she maps out only the first scene and the last; "Everything else will be what I discover in between."

Jules Feiffer, the Pulitzer Prize-winning cartoonist and playwright, for starters, of the astoundingly prescient urban apocalyptic comedy Little Murders, confesses that his theater never begins with "the need to be funny or to write a play." It comes from "politics and my anger ... a need to blow everything up." Through "sleight-of-hand," he can "pretend that this was pure entertainment." He believes that, if he does his "job right," his point of view will not be in any single character but in them all.

Rinne Groff's The Ruby Sunrise involves a woman who comes tantalizingly close to inventing television. Groff, perhaps because she began in the creative collective called Elevator Repair Service before going solo, is drawn to "the obsessive visionary person," and how the "two forces of compromise and refusal to compromise make the world go around."

Nina Raine, the only playwright here who began as a director, is drawn to research, to going into "other worlds" for inspiration. It was the deaf community in the case of Tribes, about a deaf young man in a hyperarticulate family, and medicine for Tiger Country, about indi- 
vidual dramas within a hospital. "It's to do with digging for material, isn't it?" she says, explaining her lack of interest in autobiographical family theater. "You can't endlessly generate it yourself, can you?" Jane Anderson is also more stimulated by "what I don't know about" than in autobiography. Her Defying Gravity explores the effects of the Challenger crash on different people. She also wrote the adaptation for HBO's profoundly uncompromising Olive Kitteridge. Still, that impulse away from personal story seems to come from a personal place. "I'm interested in class in America," she says, "probably because I grew up privileged and felt really guilty about it.... I got the lucky draw and I didn't know why."

Nicholas Wright's theater life began as a child actor in South Africa and includes having worked in the literary offices of those English creative cauldrons, the Royal Court and the National Theatre. Not surprisingly, perhaps, the author of Mrs. Klein, about a formidable psychoanalyst and two young women, finds that "most people are deeply contradictory and it's interesting, and truthful as well, to show as many contradictions in a character as you can."

For decades, theatergoers have marveled at how many deeply contradictory feelings can be pulled from A. R. Gurney's lifelong territory - the fading American WASP culture in which he grew up. The extravagantly prolific creator of such lives in The Cocktail Hour and Love Letters says he writes about what he knows because other material "doesn't light a fire in my gut."

Gurney, who began in academia, admires the British as "the custodians of Western drama." The British, he believes, take theater "extremely seriously," whereas American playwrights "play with theater ... play with the form a little more." He believes the job of British playwrights "is to perpetuate and amplify a wonderful old tradition" while Americans "see the basic artificiality of theater.... We tend to do whatever we can to challenge all that. "They don't like Thornton 
Wilder, the Brits," Gurney says about the writer most Americans in this volume credit as inspiration. "They don't like the way he talks about the artificiality of the form."

It means something that he and Hare, who would seem to have nothing in common, both value the response of strangers, the theatergoers. To Gurney, "the ultimate collaboration is with the audience." Hare feels the pressure of being "horribly expos[ed]" when "listening to what people really think of you." He admits he listens "to every cough."

To the community of strangers about to listen in on playwrights gathered alone but together in this clear window of a book, I suspect such exposure will be both a pleasure and a privilege. 